\title{
Copper deficiency in rats fed upon raw meat
}

\author{
By T. MOORE, B. J. CONSTABLE, K. C. DAY, \\ S. G. IMPEY AND K. R. SYMONDS \\ Dunn Nutritional Laboratory, University of Cambridge and Medical \\ Research Council
}

(Received 25 fuly 1963-Accepted 10 October 1963)

Evidence given in earlier papers (Moore, Sharman, Constable, Symonds, Martin \& Collinson, 1962; Moore, Impey, Martin \& Symonds, 1963) has supported the view that a diet of raw beef produces both skeletal and haematological abnormalities in young piebald rats. The skeletal lesions appear to be due mainly, and probably entirely, to the low calcium content of the meat. Since $\mathrm{Ca}$ requirements are much higher in young than in mature rats, the effect of a meat diet on the bones can be demonstrated most readily in weanlings. Mature rats can subsist for long periods on diets of unsupplemented meat without developing noticeable skeletal abnormalities. The haematological lesions are those of a severe microcytic anaemia, as seen in dietary deficiency of iron. Associated abnormalities are loss of the normal brown Fe-containing pigment from the anterior surfaces of the incisor teeth and hypochromotrichia. The key element for preventing both the anaemia and the two associated abnormalities caused by a diet of raw meat was found not to be $\mathrm{Fe}$, as first expected, but copper (Moore, I962a). Indications have been reported that the severity of the lesions now associated with $\mathrm{Cu}$ deficiency may be reduced by an adequate, but not excessive, intake of $\mathrm{Ca}$ (Moore et al. 1962,1963 ).

Adler (1958) observed anaemia in mice fed upon meat. Subsequently 'meat anaemia' has been studied extensively in the same laboratory by Ilan \& Guggenheim (1960, 1962) and Ilan, Kende \& Guggenheim (1960). Mice, but not rats, developed severe anaemia when fed upon raw skeletal muscle from animals of various species. Supplements of organs, particularly liver, were first tried for treating the anaemia and found to be effective. Eventually $\mathrm{Cu}$ was found to prevent or cure the anaemia (Ilan \& Guggenheim 1961; Ilan, Guggenheim \& Ickowicz, 1963; Guggenheim, Ilan, Fostick \& Tal, 1963). Ca was also beneficial, but manganese was not. Both $\mathrm{Cu}$ and $\mathrm{Mn}$ improved the utilization of the small amount of $\mathrm{Ca}$ in meat for mineralization of the bone.

Moore $(1962 b)$ reported briefly the appearance of anaemia, dental depigmentation and hypochromotrichia in rats fed upon various forms of meat and also their prevention by $\mathrm{Cu}$, but not by $\mathrm{Mn}$ or pantothenic acid. A preliminary account of breeding trials, which indicated the importance of $\mathrm{Cu}$ for lactation, was also given. Further experiments (Moore, 1963) showed that albino rats, as well as piebald, develop $\mathrm{Cu}$ deficiency when fed on raw meat. In piebalds cobalt was ineffective against the abnormalities, but they were usually prevented or ameliorated by 'domestic' cooking of the meat. Commercial processing appeared to be less effective. Evidence was 
obtained that in meat-fed rats $\mathrm{Cu}$ causes the liver to be smaller in size than in unsupplemented rats, but to have a higher fat content.

This paper gives a detailed account of the effects of raw meat in producing anaemia, dental depigmentation and hypochromotrichia in rats. Evidence is included also of the beneficial effects of $\mathrm{Cu}$ and domestic cooking, and of the ineffectiveness of other nutrients and of two forms of commercial processing.

\section{EXPERIMEN'TAL}

Rats. Pure-bred, piebald rats were used for all experiments except one, in which some groups were albino. Except in one experiment the rats were all males; they were taken for experiment at a body-weight of about $70 \mathrm{~g}$. At this stage of development they could survive for long periods without supplements of $\mathrm{Ca}$, under conditions favourable for the appearance of the abnormalities due to $\mathrm{Cu}$ deficiency.

Plan of experiments. Expt I was carried out on female rats. Its aim was to prove that our routine diet of raw minced beef was capable, when supplemented with $\mathrm{Ca}, \mathrm{Cu}$ and fat-soluble vitamins, of allowing prolonged and rapid growth. In this experiment, control rats received the stock diet used for many years in the breeding room at this laboratory. It consists of commercial rat cubes (wholemeal flour $46 \%$, Sussex-ground oats $40 \%$, white fish meal $8 \%$, dried yeast $\mathrm{x} \%$, dried skim milk $3 \%$, with added vitamins $\mathrm{A}, \mathrm{D}$ and $\mathrm{E}$ and trace elements). Milk was allowed ad lib. daily, and meat, liver, wheat (all cooked), carrots and cabbage (raw) were each given once weekly.

In each of four further experiments, groups were included that received raw minced beef, either without mineral supplements (negative controls) or with adequate supplements of $\mathrm{Cu}$ (positive controls). In the negative controls the abnormalities associated with $\mathrm{Cu}$ deficiency invariably developed. The points investigated in the various experiments were:

Expt 2. Effects of supplements of calcium pantothenate and of $\mathrm{Mn}$; effects of substituting raw mutton or pork for raw beef.

Expt 3. Effects of substituting cooked beef, corned beef or canned pork for raw beef; substitution of albino for piebald rats.

Expt 4. Effects of supplements of cobalt, of reducing the $\mathrm{Cu}$ supplement or of cooking the beef.

Expt 5. Effects of reducing the Cu supplement or of cooking the beef by autoclaving.

Raw minced steak. Prime chine, or shoulder steak, from British-reared steers, was supplied by a local butcher. He was instructed to include such portions of attached adipose tissues as are usually sold with the steak, but to exclude all bone. The steak was minced first by the butcher and reminced to a fine state on arrival at the laboratory. It was then kneaded by hand into a uniform paste and stored in glass vessels in a refrigerator until required for feeding the rats. Fresh bulk supplies of meat were prepared twice weekly.

The various supplements, other than the fat-soluble vitamins, were mixed into the meat during the kneading stage. Portions of meat, in freshly washed food-pots, were given daily to the rats. Daily inspection of the food left over by the rats indicated that 
the material was eaten uniformly, without rejection of fat particles. The excess of food from the previous day was discarded.

Determination of fats in the steak, on samples taken at different times, varied only slightly from a mean of $17 \%$. Moisture was $62 \%$ and protein (by difference, neglecting non-protein extractives and ash) $21 \%$. About $65 \%$ of the calories supplied by the steak, therefore, came from fat. The steak contained I $2 \cdot 2 \mathrm{mg} \mathrm{Ca}, 4.9 \mathrm{mg}$ Fe and $\mathrm{I} 60 \mu \mathrm{g}$ $\mathrm{Cu}$ per $100 \mathrm{~g}$ wet weight.

Cooked steak. In Expt 3 minced steak was cooked in an enamel saucepan. The meat was stirred in the saucepan with half its own weight of tap water. The saucepan was then covered with a porcelain plate, and the meat was gently boiled with occasional stirring for $90 \mathrm{~min}$. It was calculated that the tap water contributed about $2.5 \mathrm{mg}$ $\mathrm{Ca} / \mathrm{I} 00 \mathrm{~g}$ original meat.

In Expt 4 the saucepan was replaced by a closed glass casserole and the tap water by distilled water. The meat was again cooked for $90 \mathrm{~min}$, but in an oven. In Expt 5 the meat was placed in the glass casserole, without addition of water, and was autoclaved for $20 \mathrm{~min}$ at a pressure of $10 \mathrm{lb} / \mathrm{in}^{2}$.

All the cooking processes caused the meat to shrink and fat to be extruded. After cooking, the meat and surrounding fat and fluid were placed in a refrigerator, which caused the fat to solidify and the fluid to form a jelly. The mixture was then stirred up well before it was given to the rats.

The first two cooking processes, in which water was added to the meat and partly removed by evaporation, resulted in a net addition of $34 \%$ of water. The autoclaving caused an increase of $3 \%$.

Other kinds of meat. Raw mutton and pork, both from the shoulder, were obtained from the butcher in large pieces and were finely minced and kneaded in the laboratory. The mutton contained $21.3 \mathrm{~g}$ fat, $60.0 \mathrm{~g}$ moisture, $18.7 \mathrm{~g}$ protein and $128 \mu \mathrm{g} \mathrm{Cu} /$ roo $\mathrm{g}$. The pork contained $10.3 \mathrm{~g}$ fat, $70.4 \mathrm{~g}$ moisture, $19.3 \mathrm{~g}$ protein and ror $\mu \mathrm{g} \mathrm{Cu}$ per $100 \mathrm{~g}$. According to food tables (McCance \& Widdowson, 1960), mutton and pork resemble beef in containing only small amounts of $\mathrm{Ca}$. Their $\mathrm{Fe}$ contents appear to be about half that of beef.

Canned corned beef contained $14.3 \mathrm{~g}$ fat, $5^{\mathrm{I}} \cdot 7 \mathrm{~g}$ moisture, $34^{\circ} \mathrm{Og}$ protein and I $37 \mu \mathrm{g} \mathrm{Cu} / 100 \mathrm{~g}$. According to its commercial label, it came from Argentina and was made from cooked beef, salt, sugar, sodium nitrate and sodium nitrite. Canned chopped pork contained $22 \mathrm{~g}$ fat, $5 \circ \mathrm{g}$ moisture, $28 \mathrm{~g}$ protein and IoI $\mu \mathrm{g} \mathrm{Cu} / 100 \mathrm{~g}$. It came from Denmark and was made from chopped pork, potato starch, salt, sugar and sodium nitrate. Both these products were minced finely before they were given to the rats. $\mathrm{Ca}$ and $\mathrm{Fe}$ were not determined.

Supplements. Cu was mostly added to the meat given to the positive control groups as sulphate at the level of $10 \mu \mathrm{g} \mathrm{Cu} / \mathrm{g}$, but certain groups in Expts 4 and 5 received smaller $\mathrm{Cu}$ supplements in the same form. Mn was tested at the level of $30 \mu \mathrm{g}$, and $\mathrm{Co}$ at $10 \mu \mathrm{g} / \mathrm{g}$ meat, both as sulphate. Pantothenic acid was given as its $\mathrm{Ca}$ salt, at the level of $20 \mu \mathrm{g}$ of the salt/g. All the rats were given adequate weekly doses of vitamins $\mathrm{A}, \mathrm{D}, \mathrm{E}$ and $\mathrm{K}$ separately from the rest of their diet. 


\section{PROCEDURE}

Expt I lasted for 14 weeks, the others for about 7 weeks. Before being killed, the rats were anaesthetized with ether and then bled from the inferior vena cava. Redcell count, haemoglobin and packed cell volume were measured by routine methods.

The upper incisor teeth were extracted, and the degree of pigmentation of their anterior surfaces was assessed by comparison with five pairs of 'standard teeth'. These had been selected as showing even graduations between completely depigmented teeth (white) and normal teeth (dark brown). As before (Moore et al. 1962), a score of 4 was given for each normal tooth and o for each completely white tooth, making a maximum of 8 and a minimum of o for each pair. Dental depigmentation is well known not to be a specific effect of Cu deficiency: it can be caused by several dietary defects, notably by lack of vitamin A or vitamin E (Moore, 1943).

The degree of hypochromotrichia was assessed in our earlier experiments by inspecting the hair on the head, shoulders and back, which was recorded as being normal or slightly grey, grey or very grey. Later we selected, in each series of experiments, the rats with the darkest hair and the rats with the most grey hair. Three other rats to show the smoothest possible gradient between the two extremes were then chosen. Pl. I shows a set of rats' carcasses selected for this purpose. The scoring, to be consistent with that for dental pigmentation, was 4 for normal hair and o for maximum greyness. Attempts to keep a set of carcasses as permanent standards were defeated by changes in the colour of the hair during storage.

It was not a major aim in these experiments to study further the $\mathrm{Ca}$ deficiency induced by meat diets. At autopsy, however, the usual gross signs of Ca deficiency were noticed in many animals. In certain groups in Expt 5, superficial observations were supplemented by determinations of the ash contents of the bones.

\section{RESULTS}

Expt I. Fig. I shows the curve for the mean weight increases of six young female rats, fed upon raw beef-steak supplemented with $\mathrm{Ca}\left(0.5 \% \mathrm{CaCO}_{3}\right)$ and $\mathrm{Cu}(10 \mu \mathrm{g} / \mathrm{g})$. The lower curve relates to a control group of five similar rats given the stock diet. The weight increases were significantly greater $\left(P^{\prime}<0.01\right)$ in the rats fed upon meat. At least part of the higher body-weight in the meat-fed animals was due to greater fat storage. Although body lengths did not differ significantly between groups, the mean girth, measured round the abdomen, was $19.3 \mathrm{~cm}$ in the meat-fed rats against $17.0 \mathrm{~cm}$ in those given stock diet $(P<0.01)$. The mean weight of the combined perinephric and periuterine adipose tissues averaged $36 \cdot 2 \mathrm{~g}$ in the meat-fed rats against $26 \cdot 4 \mathrm{~g}$ in those given the stock diet $(P<0.01)$. Throughout this experiment the rats in both groups remained in good health, as evidenced by normal activity and sleek coats.

Expts 2-5. Our results, summarized in Tables $\mathrm{I}-4$, indicated that anaemia, dental depigmentation and hypochromotrichia always developed in rats fed on raw meat and were always prcvented by adequate supplements of $\mathrm{Cu}$. 'Domestic' cooking also prevented these abnormalities almost completely. 
Efficacy of $\mathrm{Cu}$. In Expts 2, 3 and 4 the mean percentages of haemoglobin in the blood of piebald rats fed on raw beef without $\mathrm{Cu}$ supplements were $9.35,5.3 \mathrm{I}$ and 8.27. In the animals given $\mathrm{Cu}, 10 \mu \mathrm{g} / \mathrm{g}$ meat, the corresponding percentages were 16. $5^{2}, 14.43$ and 15.18 . In the albino rats in Expt 3 haemoglobin percentages averaged 7.65 in the unsupplemented group and $14 \cdot 18$ in the rats given $\mathrm{Cu}$. For red-cell counts the difference between the rats with and without $\mathrm{Cu}$ was less striking, but the differences for packed cell volume were similar to those for haemoglobin.

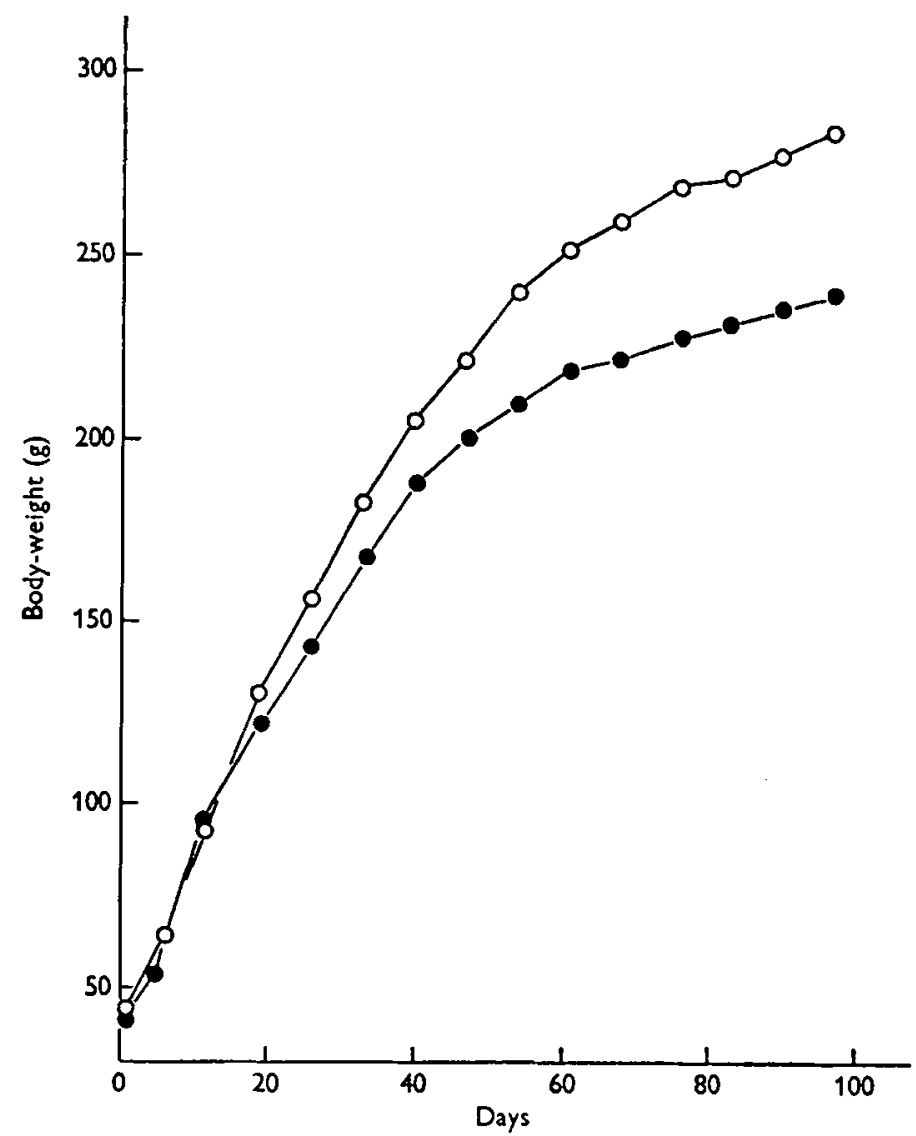

Fig. I. Weight increases of young female piebald rats fed either upon stock diet, or upon raw beef-steak adequately supplemented with copper, calcium and fat-soluble vitamins. $\bullet-\bullet$, mean body-weights for five rats fed on stock diet; $0-0$, mean body-weights for six rats fed on steak.

In the same experiments the mean scores for dental pigmentation in piebald rats, without mineral supplements, were $\mathrm{I} \cdot 2, \mathrm{I} \cdot 0,3 \cdot 0$, compared with $8 \cdot 0,7 \cdot 5$ and $8 \cdot 0$ when $\mathrm{Cu}$ was given. In the albinos the mean scores were $\mathrm{I} \cdot 3$ without $\mathrm{Cu}$ and 8.0 with $\mathrm{Cu}$.

Hypochromotrichia was invariably prevented by $\mathrm{Cu}$ at the ro $\mu \mathrm{g}$ level. With a diet of raw meat without $\mathrm{Cu}$, the first signs of greyness were usually seen within 14 days.

Minimal dose of $C u$. In groups of rats given I (Expt 4), 2.5 or $5^{\circ} \circ($ Expt 5$) \mu \mathrm{g} \mathrm{Cu} / \mathrm{g}$ meat, haemoglobin percentages averaged II 41 I 13.77 and I $3 \cdot 86$, compared with 8.27, 
है

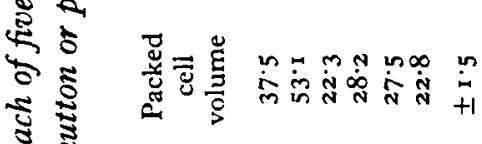

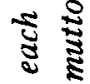

जी

की 8

. 5

(ิ)

(3)

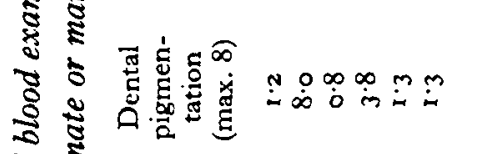

ปี

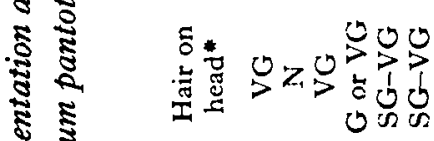

零

हूँ

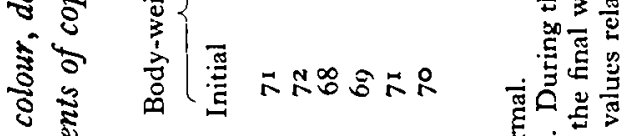

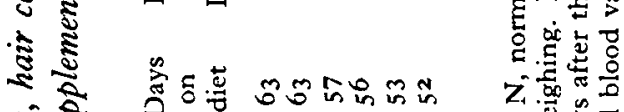

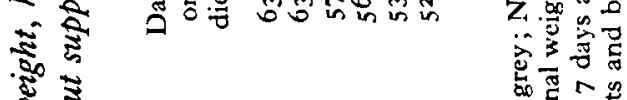

离

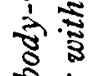

के

$\sum_{i}^{\infty} \cdot \frac{\pi}{\sqrt{2}}$

की

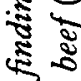

起

$\sum^{2}$

i

造旅

$\therefore \frac{\mathbb{E}}{0}$

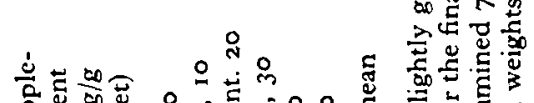

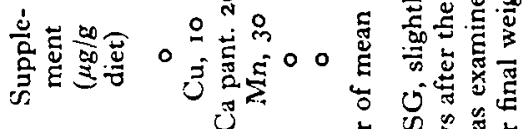

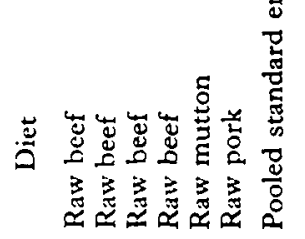

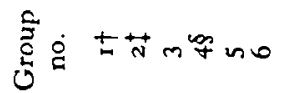

- 5

¿

हो

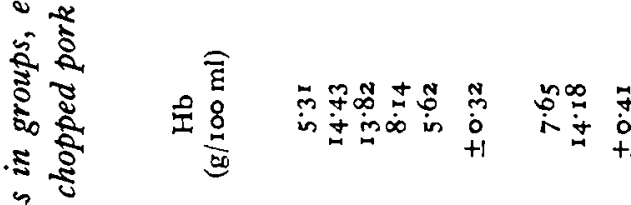

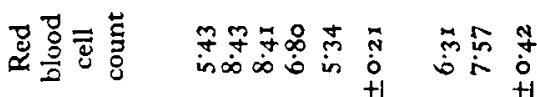

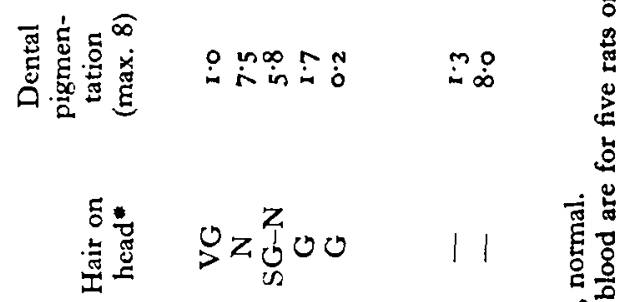

ङ

है

है

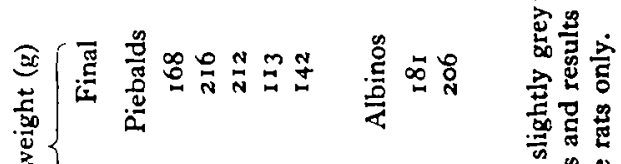

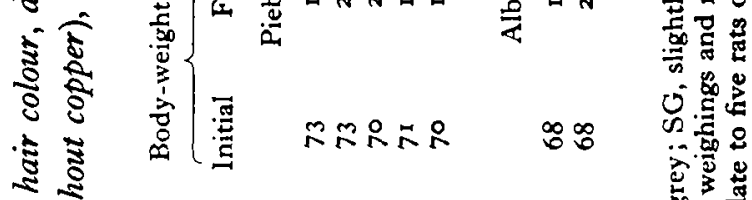

$\stackrel{2}{\approx}$

:

$\frac{8}{8} \cdot \frac{5}{3}$

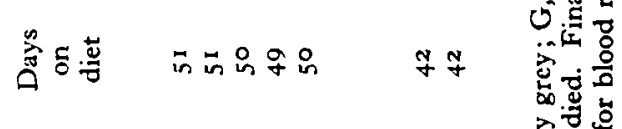

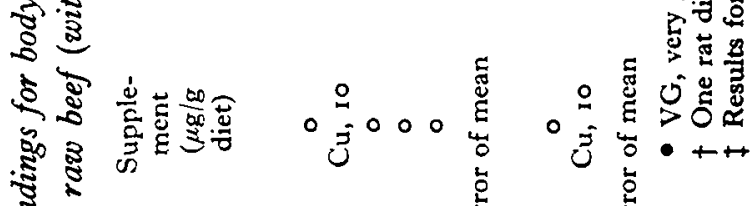

यक

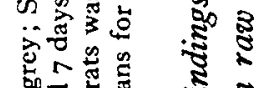

结 5

$0 . \stackrel{3}{2} \Sigma$

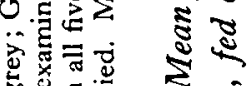

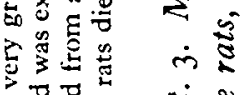

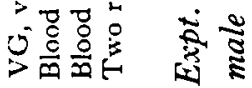

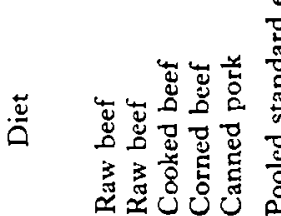

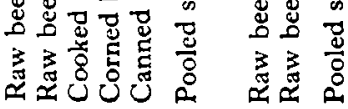

$\frac{\dot{y}}{\frac{0}{0}}$

总宫 
है

-

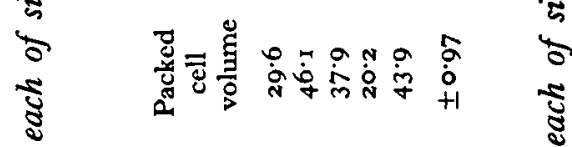

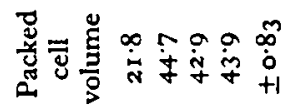

芌

赵

है

है ह

ธี

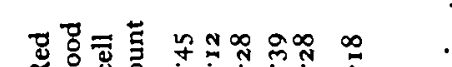

क्षे

.

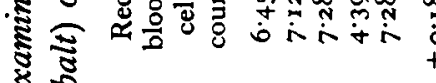

के

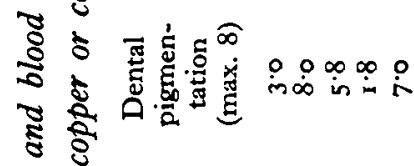

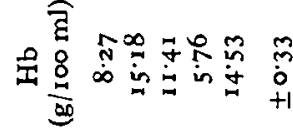

ㅎำ

密

.$\frac{2}{5}$

旅

ฐ

竎

竎 $\frac{2}{\sqrt[3]{2}}$

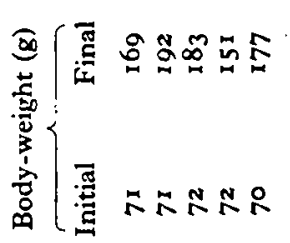

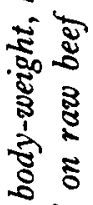

这

뭉

sิ

की

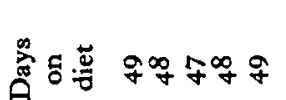

$+\frac{1}{5}$

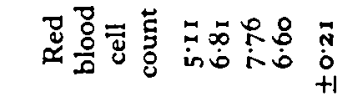

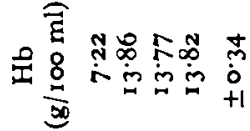

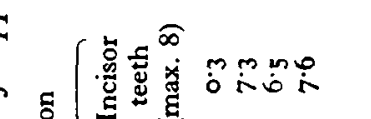

है

을

㻤

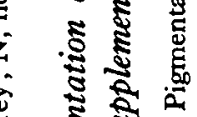

\{

공

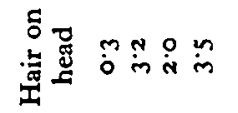

क

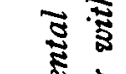

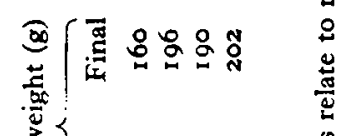

胥

ङ

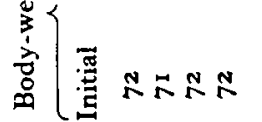

总

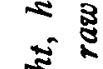

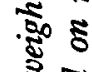

दे ?

ह

का

:

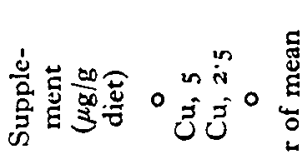

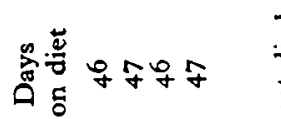

: 
7.22 and 7.22 in the corresponding groups given no $\mathrm{Cu}$. The influence of $\mathrm{Cu}$ on the blood picture was therefore apparent at all these levels. Evidence that the $\mathrm{I} \cdot 0$ and $2.5 \mu \mathrm{g}$ levels were not quite adequate, however, could be seen in the obvious greyness of several of the rats given these low doses. As a further indication that the $\mathrm{r} \cdot 0 \mu \mathrm{g}$ level was inadequate, decidedly low haemoglobin percentages of $9.95,9.70$ and 10.20 were observed in three of the six rats dosed. The lowest individual haemoglobin percentage in a total of twenty-three rats given $\mathrm{Cu}$ at the $10 \mu \mathrm{g}$ level was 13.35 . Even the $5 \mu \mathrm{g}$ level was not quite adequate on the evidence of slight hypochromotrichia in three out of five rats. To illustrate the extreme severity of the anaemia developed in some of the undosed animals given raw beef, values may be quoted for one of the rats in Expt 4. The red blood cell count was 3.73 million, haemoglobin $4.25 \mathrm{~g} / 100 \mathrm{ml}$ and packed cell volume $16.9 \%$. Several other rats, undosed or dosed with inactive substances, had equally severe anaemia.

Influence of $\mathrm{Cu}$ on body-weight increase. In all our experiments adequate doses of $\mathrm{Cu}$ augmented the mean body-weight increase (Table 5). The rates of growth with $\mathrm{Cu}$, however, were still much below those to be expected if supplements of both $\mathrm{Cu}$ and $\mathrm{Ca}$ had been given.

Table 5. Mean increases in body-weight, during the whole experimental period, in groups of rats fed on raw beef with or without supplements of copper

$\begin{array}{lcccc}\begin{array}{c}\text { Expt } \\ \text { no. }\end{array} & \begin{array}{c}\text { Cu supplement } \\ (\mu \mathrm{g} / \mathrm{g} \text { meat })\end{array} & \begin{array}{c}\text { Mean increase in } \\ \text { body-weight }(\mathrm{g})\end{array} & \begin{array}{c}\text { Cu supplement } \\ (\mu \mathrm{g} / \mathrm{g} \text { meat })\end{array} & \begin{array}{c}\text { Mean increase in } \\ \text { body-weight (g) }\end{array} \\ \text { I } & 0 & 97 & 10 & 120 \\ 2 & 0 & 95 & 10 & 143 \\ 2 \text { (albinos) } & 0 & 113 & 10 & 138 \\ 3 & 0 & 98 & 10 & 121 \\ 4 & 0 & 88 & 5 & 125\end{array}$

Mutton and pork. Both these meats, eaten raw, resembled beef in producing anaemia, dental depigmentation and hypochromotrichia. The preventive action of $\mathrm{Cu}$ was not tested.

Inefficacy of calcium pantothenate, $\mathrm{Mn}$ and $\mathrm{Co}$. The abnormalities attributable to $\mathrm{Cu}$ deficiency were not prevented by supplements of $20 \mu \mathrm{g}$ calcium pantothenate $/ \mathrm{g}$ (Table I), which was tried because pantothenic acid deficiency can give rise to hypochromotrichia (György \& Poling, 1940; Unna \& Sampson, 1940). Mn, $30 \mu \mathrm{g} / \mathrm{g}$, was ineffective, except possibly for slight protection against dental depigmentation. Co, 1o $\mu \mathrm{g} / \mathrm{g}$, was also ineffective. Since the abnormalities in the group given Co appeared to be somewhat more severe than in the negative controls, the potency of $\mathrm{Co}$ as an antagonist to $\mathrm{Cu}$ requires further investigation.

Effect of cooking. Three tests with stewed (Expts 3 and 4) or autoclaved (Expt 5) meat all indicated that the ability of the meat to produce $\mathrm{Cu}$ deficiency had been lost. Thus haemoglobin percentages were $13.82,14.53$ and 13.82 as compared with 5.31 , 8.27 and 7.22 in the corresponding negative control groups. No signs of Cu deficiency were observed, other than slight greyness or dental depigmentation in some animals. 
Commercial processing. Results for commercially cooked meats were different. In the groups given corned beef and chopped ham the mean percentages of haemoglobin were 8.14 and 5.62 respectively, compared with 14.43 in the positive group. In both the groups given processed meats the hair was grey and the teeth almost completely depigmented. Growth increases were much lower than in the rats given raw beef without $\mathrm{Cu}$. Preliminary experiments have indicated that the low weight increases in rats fed upon corned beef, unlike those in rats fed upon raw beef, cannot be fully corrected by combined supplementation with $\mathrm{Ca}$ and $\mathrm{Cu}$.

Calcification. The ash contents of the undried femurs were measured in the rats of groups 19 (raw beef only), 20 (raw beef $+5 \mu \mathrm{g} \mathrm{Cu} / \mathrm{g}$ ) and 22 (autoclaved beef) (Table 4). The mean percentages were $13.1 \pm 0.87,13.9 \pm 0.73$ and $13.6 \pm 0.47$. These values may be compared with the mean value of $42 \%$ previously found in rats given adequate supplements of $\mathrm{Ca}$ continuously (Moore et al. 1963 ). Neither supplements of $\mathrm{Cu}$ nor cooking, therefore, had any significant influence in raising the low ash content of the bones. There were, indeed, indications that the supplements of $\mathrm{Cu}$ sometimes increased the incidence of rib fracture, presumably a reflection of the slightly increased growth rate.

Size, and fat content, of livers. In all these experiments the weight of the liver was recorded, and in many instances its fat content was measured. In sixteen of the negative control rats given raw beef, the liver averaged $6.6 \%$ of the body-weight, with a mean fat content of $4.9 \%$. For sixteen rats that received raw beef with $10 \mu \mathrm{g} \mathrm{Cu} / \mathrm{g}$, the corresponding percentages were 4.8 and 7.5 . Thus the effect of $\mathrm{Cu}$ deficiency was to increase the size of the liver, in relation to body-weight, and to decrease its fat percentage.

\section{DISCUSSION}

Our results indicate that the abnormalities regularly developed by young rats fed upon raw meat (beef, mutton or pork) include anaemia, dental depigmentation and hypochromotrichia. On the evidence of experiments with beef only, all these abnormalities may be prevented either ( $\mathrm{I}$ ) by the addition of adequate supplements of $\mathrm{Cu}$ to the meat, or (2) by cooking the meat.

Interaction of $\mathrm{Cu}$ and $\mathrm{Fe}$. Explanations of these clear-cut findings can still only be hypothetical. Anaemia and dental depigmentation, we may notice, are bound up with Fe metabolism, since both haemoglobin and the brown dental pigment contain this element. There is as yet no evidence, however, to suggest that $\mathrm{Fe}$ is concerned in preventing hypochromotrichia, whereas the role of $\mathrm{Cu}$ in the formation of melanin pigments is well known (Underwood, 1956).

Readily absorbable $\mathrm{Cu}$ is presumably required both for those roles in which it aids the utilization of $\mathrm{Fe}$ and for those in which it has direct action on the tissues. At least part of the $\mathrm{Cu}$ held in animal tissues is known to be combined with protein (Frieden, 1962), and for this reason it may be poorly absorbed during digestion. It seems probable, therefore, that the same beneficial effect may be produced either by supplying inorganic $\mathrm{Cu}$ or by releasing as a result of cooking the $\mathrm{Cu}$ naturally present in the meat from its binding to protein. 
This theory may be reminiscent of the long-standing conception that Fe occurs in food partly in ionizable, readily available form, and partly in combined form, not readily available. Cooking may increase the proportion of available Fe (Shackleton \& McCance, 1936). How far the availability of Fe from foods depends on their containing readily available $\mathrm{Cu}$, rather than ionizable $\mathrm{Fe}$, is now open to question. Early work by Schultze, Elvehjem \& Hart (1934) showed that $\mathrm{Cu}$ in the form of its haematoporphyrin is poorly absorbed by rats. A matter requiring further investigation is the failure of the commercially cooked meats, corned beef and canned pork, to prevent the signs of $\mathrm{Cu}$ deficiency.

$\mathrm{Cu}$ and fat metabolism. One of the effects of cooking on meat is to liberate fat from the tissues. It is possible, therefore, that the ease of digestion of the fat, by the rat, may be changed. How far these changes in the state of the dietary fat can affect the $\mathrm{Cu}$-deficiency syndrome cannot be assessed. It is clear, however, from our results on weight and fat content of the liver that $\mathrm{Cu}$ can affect fat metabolism, either directly or indirectly.

$\mathrm{Cu}$ requirements. Schultze et al. (1934) found that $5 \mu \mathrm{g} \mathrm{Cu}$ daily was enough to promote haemoglobin formation in anaemic rats, but considered that an intake of ro $\mu \mathrm{g}$ was desirable. Recently Warren $(1962)$ has given $50 \mu \mathrm{g}$ as the daily requirement for the prevention of $\mathrm{Cu}$ deficiency in rats fed upon milk. A rat eating $3 \circ \mathrm{g}$ raw steak daily, without $\mathrm{Cu}$ supplements, must ingest about $4^{8} \mu \mathrm{g} \mathrm{Cu}$. This intake, if efficiently absorbed, would obviously be adequate. Our experiments also indicated that an extra intake of inorganic $\mathrm{Cu}$ at the rate of $\mathrm{I} \mu \mathrm{g} / \mathrm{g}$ meat, totalling $30 \mu \mathrm{g}$ daily, was sufficient to prevent all but minor signs of deficiency in most of the rats.

It appears, therefore, that the $\mathrm{Cu}$ of raw meat is present in a form unavailable to the rat and that its liberation could explain the beneficial effects of cooking the meat. Apparently the protein in the meat did not chelate, or otherwise immobilize, additional $\mathrm{Cu}$ added to the meat after the death of the bovine. From our earlier experiments (Moore et al. 1963) we may also deduce that a diet of raw meat does not interfere with the absorption of $\mathrm{Ca}$, added as carbonate.

General. The production of hypochromotrichia in rats fed on raw but not on cooked beef recalls reports of the production of pale-coloured hair ('cotton fur') and anaemia in mink given diets containing raw fish (Helgebostad \& Martinsons, 1958; Stout, Oldfield \& Adair, I $960 a, b$ ). In parallel with our results, abnormalities were prevented by cooking the fish. $\mathrm{Cu}$, however, appeared to be ineffective against 'cotton fur'.

The ability of $\mathrm{Cu}$ to improve the growth rates of rats, observed consistently in our experiments, brings to mind observations that addition of $\mathrm{Cu}$ has been found beneficial for the fattening of pigs (Braude, Townsend, Harrington \& Rowell, 1962). The pigs received $25^{\circ} \mu \mathrm{g} \mathrm{Cu} / \mathrm{g}$ dry diet, which consisted mainly of cereal products. There is no evidence that the diet without the mineral mixture was deficient in $\mathrm{Cu}$.

Finally, we must emphasize that our experiments were carried out under conditions known to favour the appearance of the abnormalities under investigation. Thus our rats were young and were not given supplements of $\mathrm{Ca}$. As already mentioned (Moore et al. 1963), adult rats develop hypochromotrichia, but not anaemia or severe 
dental depigmentation, when given raw beef without mineral supplements. Ca without $\mathrm{Cu}$ is effective against hypochromotrichia in adults (Moore et al. 1963). In young rats $\mathrm{Ca}$, in adequate but not excessive doses, reduces the severity of anaemia and dental depigmentation, but does not prevent hypochromotrichia. The mechanism by which $\mathrm{Ca}$ affects the metabolism of $\mathrm{Cu}$, which in turn affects the metabolism of $\mathrm{Fe}$, remains unexplained (Moore et al. 1962). The high proportion of the calorie intake derived from fat, and the ability of the rat to thrive under these conditions if given adequate mineral supplements, have already been mentioned (Moore et al. 1963).

\section{SUMMARY}

I. Young male piebald rats weighing $70 \mathrm{~g}$ were fed on a basal diet of raw minced beef, without mineral supplements. At this stage of development, the degree of calcium deficiency attained over a period of 7 weeks was seldom fatal, and fairly rapid preliminary growth occurred.

2. All the negative control rats developed anaemia, dental depigmentation and hypochromotrichia.

3. Supplements of copper, as sulphate, at 1o $\mu \mathrm{g} / \mathrm{g}$ beef, invariably and completely prevented the anaemia and associated abnormalities. Weight gains were always increased by $\mathrm{Cu}$. Doses of $\mathrm{Cu}$ down to $\mathrm{r} \cdot 0 \mu \mathrm{g}$ were at least partly effective.

4. Manganese, cobalt and calcium pantothenate $(30$, 10 and $20 \mu \mathrm{g} / \mathrm{g})$ were ineffective.

5. Cooking the beef, which when unsupplemented contained $\mathrm{I} \cdot 6 \mu \mathrm{g} \mathrm{Cu} / \mathrm{g}$, virtually prevented the anaemia and associated lesions.

6. Abnormalities similar to those seen in rats fed on raw beef were also observed in rats fed on raw mutton or pork or on commercially canned beef or pork.

7. The livers of rats fed on raw beef, without $\mathrm{Cu}$, were larger, as a percentage of the body-weight, than those of rats given $\mathrm{Cu}$. The percentage of fat in the livers was usually somewhat higher when $\mathrm{Cu}$ was given than when it was withheld.

8. Albino rats given raw beef also developed anaemia and dental depigmentation, which were prevented by $\mathrm{Cu}$.

9. Young female piebald rats, fed on raw steak supplemented with both $\mathrm{Cu}$ and $\mathrm{Ca}$, remained in good health. Their weight increases were significantly greater than those of control rats fed on a stock diet.

We thank Dr L. J. Harris for his valuable criticism and Dr J. M. Walshe and Mr A. Ward for determination of copper and fat respectively.

\section{REFERENCES}

Adler, S. (1958). Bull. Res. Coun. Israel, 7 E, 9.

Braude, R., Townsend, M. J., Harrington, G. \& Rowell, J. G. (1962). J. agric. Sci. 58, 251.

Frieden, F. (1962). In Horizons in Biochemistry, p. 46r. [M. Kasha and B. Pullman, editors.] New York: Academic Press Inc.

Guggenheim, K., Ilan, J., Fostick, M. \& Tal, E. (1963). F. Nutr. 79, 245.

György, P. \& Poling, C. E. (1940). Science, 92, 202.

Helgebostad, A. \& Martinsons, E. (1958). Nature, Lond., r8r, 1660.

Ilan, J. \& Guggenheim, K. (I960). Nature, Lond., $187,698$. 
Ilan, J. \& Guggenheim, K. (196I). Bull. Res. Coun. Israel, 9E, r7r.

Ilan, J. \& Guggenheim, K. (1962). F. Nutr. 76, 298.

Ilan, J., Guggenheim, K. \& Ickowicz, M. (1963). Brit. F. Haemat. 9, 25.

Ilan, J., Kende, M. \& Guggenheim, K. (1960). Blood, I6, I1 55 .

McCance, R. A. \& Widdowson, E. M. (r960). Spec. Rep. Ser. med. Res. Coun., Lond., no. 297.

Moore, T. (1943). Biochem. F. 37, I12.

Moore, T. (1962a). Brit. med. F. i, 689 .

Moore, T. (1962b). Proc. Nutr. Soc. 21, xxxviii.

Moore, T. (1963). Proc. Nutr. Soc. 22, xvii.

Moore, T., Impey, S. G., Martin, P. E. N. \& Symonds, K. R. (1963). F. Nutr. 8o, 162.

Moore, T., Sharman, I. M., Constable, B. J., Symonds, K. R., Martin, P. E. N. \& Collinson, E. (1962). 7. Nutr. 77, 415 .

Schuitze, M. O., Elvehjem, C. A. \& Hart, E. B. (1934). F. biol. Chem. ro6, 735.

Shackleton, L. \& McCance. R. A. (1936). Biochem. F. 30, 582.

Stout, F. M., Oldfield, J. E. \& Adair, J. (1960a). F. Nutr. 7o, 42 I.

Stout, F. M., Oldfield, J. E. \& Adair, J. (1960b). F. Nutr. 72, 46.

Underwood, E. J. (1956). Trace Elements in Human and Animal Nutrition, p. 7r. New York: Academic Press Inc.

Unna, K. \& Sampson, W. L. (1940). P'roc. Soc. exp. Biol., N.Y., 35, 309.

Warren, P. J. (1962). Brit. F. Nutr. 16, 167.

\section{EXPLANATION OF PLATE}

Carcasses of rats graded for protection against hypochromotrichia. The rat on the extreme right, score 4, had been fed on raw beef, supplemented with $10 \mu \mathrm{g}$ copper/g. The rat on the extreme left, score 0 , had been fed on raw beef, without copper supplementation. The remaining rats were chosen to show intermediate grades of protection. 
British Fournal of Nutrition, Vol. I8, No. I

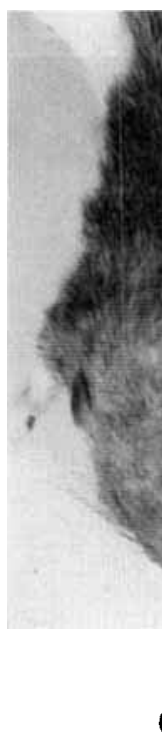

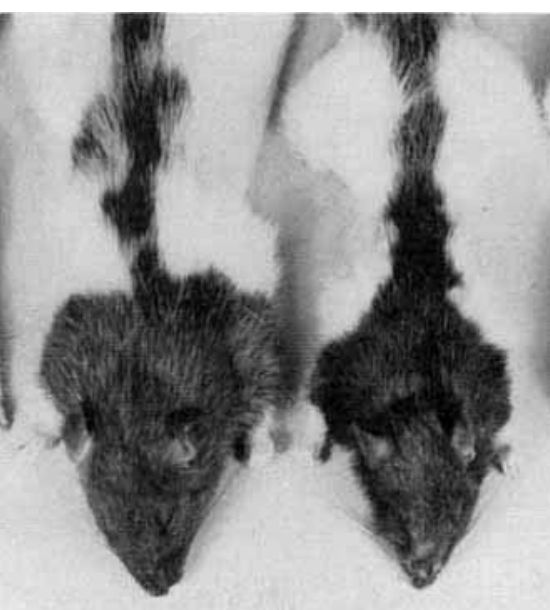

0

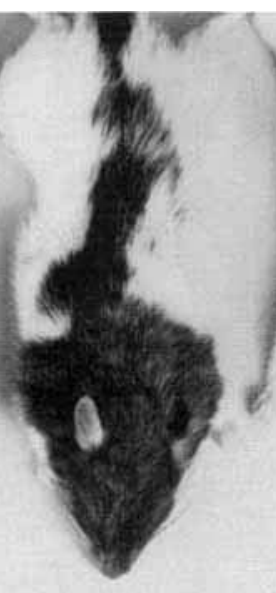

.

(2)

2

T. MOORE AND OTHERS

(Facing p. I46) 